\title{
Modeling and Simulation of Closed Loop Controlled Buck Converter for Solar Installation
}

\author{
A.Kalirasu and S.S.Dash
}

\begin{abstract}
The stand-alone photo-voltaic energy system requires storage to meet the energy demand during period of low solar irradiation and night time. Storage batteries account for the most PV system failures and contribute significantly to both initial and the eventual replacement cost. Switch mode DC to DC converters are used to match the output of a PV generator to a variable load. This paper deals the design of DC to DC converter which makes voltage is maintained at a specified value. Digital simulation of open loop and closed loop controlled buck converter for solar installation is discussed. The simulation results are compared with the theoretical results. This converter has advantages like improved power factor, fast response and reduced hardware.
\end{abstract}

Index Terms—Buck converter, Solar cells, PV cells.

\section{INTRODUCTION}

Recently, the more and more growing interest in applications of Renewable Energy Sources (RES), with all the related problems of their optimal exploitation, has increased the need of experimental equipment to carry out measurements and tests, without the direct use of the renewable source. As a matter of fact, to investigate the behavior of a photovoltaic generator (PV), a wide outer surface is needed, since the produced energy depends on solar irradiance and temperature; moreover the weather conditions are not always reproducible. In this case the necessary investment to set up an experimental plant can be made severe by the continuous evolution of the involved technologies. A possible way to reproduce the behavior of a renewable source, whose electrical characteristic lies on a $\mathrm{I}-\mathrm{V}$ plane (as in the case of a PV generator), is to use the I-V curve as a signal reference to suitably control a switching DC/DC converter. All these considerations suggest that any renewable source should be replaced by a hardware system capable of copying its behavior accurately. As for PVs, methodologies to obtain the I-V curves by using different DC/DC converter topologies are presented in [1]-[5]. In [4] a bi-directional $\mathrm{DC} / \mathrm{DC}$ electronic converter is set up to measure and emulate the I-V behavior of a photovoltaic array. The control of such converters is based on the acquisition of all I-V data of a real PV array, without considering any mathematical relation between $\mathrm{I}$ and $\mathrm{V}$, so its operation is

Manuscript received October 15, 2009.

A.Kalirasu, is research scholar of Sathyabama University, Chennai, Tamilnadu, India. (e-mail: akalirasu@yahoo.co.in).

Dr.S.S.Dash, Professor in Electrical Engineering Department, S.R.M. University, Chennai-603203 Tamilnadu, India (e-mail:munu_dash_2k@yahoo.com). possible only in certain precise working conditions and if a highly performing and expensive DSP board, for data storage and processing, is used. Finally in [5] a real time circuit simulator of photovoltaic modules is presented, but no detailed study on the converter control design with regard to stability and dynamics is reported. A new approach to obtain $\mathrm{I}-\mathrm{V}$ and $\mathrm{P}-\mathrm{V}$ curves of photovoltaic modules by using DC/DC converters is given by [10]. A DC/DC converter based circuit model for a solar photovoltaic array is given by [11]- [13]. A new approach to mobile photo-voltaic systems is proposed; the system described in this paper is of very low power $(5 \mathrm{~W})$ and is intended mainly for recharging or powering small portable electronics devices [14]. Analysis of the buck converter for scaling the supply voltage of digital circuits is presented [15]. DC-DC of the buck type, MPPT command and circuit command buck $(\mathrm{CCB})$ have analysed in Pspice and in experiments the operation of a PV system [16]. An integrated circuit approach, lowest voltage switching (LVS), for boundary mode buck converters are presented [17].

So far most Power Conversion Systems (PCSs) are mainly tested with a constant DC source. The above literature does not deal with a closed loop controlled buck converter system for solar installation. This work makes an attempt to simulate closed loop controlled buck converter. The paper is organized as follows: The second section of this paper deals with PV cell system. The third section of this paper deals with operational principle of buck converter. Simulation results are shown in section IV. The conclusion is given in section V.

\section{PV CELL SYSTEM}

The density of power radiated from the sun (referred to as the "solar energy constant") at the outer atmosphere is $1.373 \mathrm{kw} / \mathrm{m} 2$. The final incident sun light on the earth surface has the peak density of $1 \mathrm{kw} / \mathrm{m} 2$ at noon in the tropics. The technology of photovoltaic (PV) is essentially concerned with the conversion of this energy in to usable electric form. The basic element of the PV system is the solar cell. Solar cell can convert the energy of sunlight directly into electricity. A simplified equivalent circuit of a solar cell consists of a current source in parallel with a diode variable resistor is connected to the solar cell generator as a load. The well-known general mathematical model for a PV cell is obtained by describing the relation between its terminal current and voltage through the single-diode equivalent circuit of the cell, reported in Fig. 1 [6][8]and [9]. It is described as a current source in parallel with the junction as shown in equation (1): 
$\mathrm{I}=\mathrm{I}_{\mathrm{LG}}-\mathrm{I}_{\mathrm{OS}}\left\{\exp \left[\mathrm{q}\left(\mathrm{V}+\mathrm{I}_{\mathrm{n}} \mathrm{R}_{\mathrm{s}}\right) / A k T\right]-1\right\}-\left(\mathrm{V}+\mathrm{I}_{\mathrm{n}} \mathrm{R}_{\mathrm{s}}\right) / \mathrm{R}_{\mathrm{sh}}$

$\mathrm{I}_{\mathrm{LG}}=\left[\mathrm{I}_{\mathrm{SCR}}+\mathrm{K}_{\mathrm{I}}\left(\mathrm{T}-\mathrm{T}_{\mathrm{r}}\right)\right] \lambda / 1000$

$\mathrm{I}_{\mathrm{OS}}=\mathrm{I}_{\mathrm{OR}}\left[\mathrm{T} / \mathrm{T}_{\mathrm{r}}\right]^{3} \exp \left[\mathrm{qE}_{\mathrm{GO}}\left(1 / \mathrm{T}_{\mathrm{r}}-1 / \mathrm{T}\right) / \mathrm{BK}\right]$

Where I and V are cell output current and voltage. Ios is cell reverse saturation current, $\mathrm{T}$ is cell temperature in $0 \mathrm{C}, \mathrm{k}$ is Boltzmann's constant, $\mathrm{q}$ is electronic charge, $\mathrm{K} 1(=0.0017)$ short-circuit current temperature coefficient at ISCR ,A is solar irradiation in $\mathrm{W} / \mathrm{m} 2$, ISCR is short-circuit current at 25 $0 \mathrm{C}$ and $1000 \mathrm{~W} / \mathrm{mi}$, ILG is light-generated current, EGO is band gap for silicon. $\mathrm{B}=\mathrm{A}(=19.2)$ are the ideality factors, $\mathrm{Tr}$ $(=301.180 \mathrm{~K})$ is reference temperature, IOR is cell saturation current at T, Rsh is shunt resistance and $\mathrm{R}$ is series resistance.

There are two possibilities to define the PV cell model parameters. Two diode model is based on the knowledge of the theoretical characteristics, usually provided by manufacturers [7] and one diode model is based on the model parameters identification, from experimental data and interpolation.

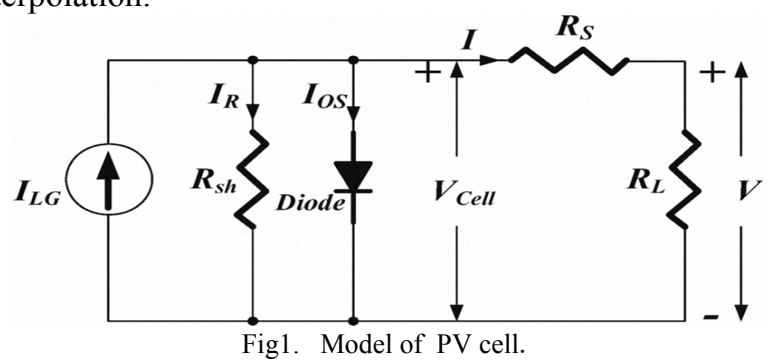

The stand-alone photo-voltaic energy system requires storage to meet the energy demand during period of low solar irradiation and night time. The battery storage in a solar system should be properly controlled to avoid catastrophic operating condition like overcharging or frequent deep discharging. Storage batteries account for the most PV system failures and contribute significantly to both initial and the eventual replacement cost. Charge controllers regulate the charge transfer and prevent the battery from being excessively charged and discharged. Switch mode DC to DC converters are used to match the output of a PV generator to a variable load. The DC to DC converters allow the charge current to be reduced continuously in such a way that the resulting battery voltage is maintained at a specified value. A practical photovoltaic energy conversion system block diagram is shown in Fig.2.

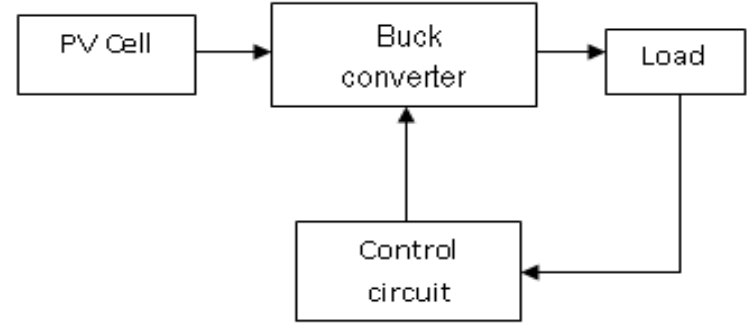

Fig2. Block Diagram of PV Installation system

\section{OPERATIONAL PRINCIPLE}

In the Figure 3 can be seen a principle scheme for a buck converter. For buck converter presented below is presumed that is working in continuous-conduction mode.

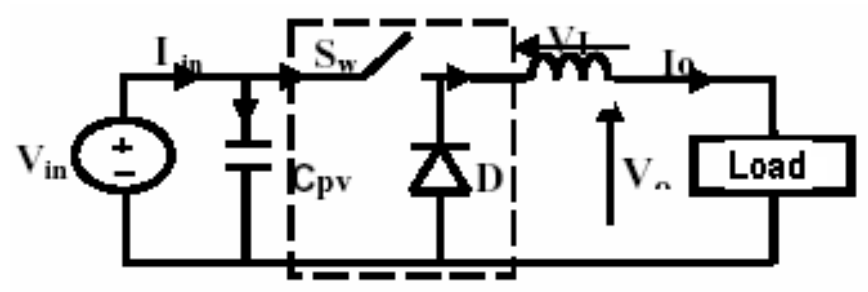

Fig3. Buck (DC-DC) converter

A Buck converter operates in continuous mode if the current through the inductor (Io) never falls to zero during the commutation cycle. In this mode, the operating principle is described by the waveform on Figure 4.

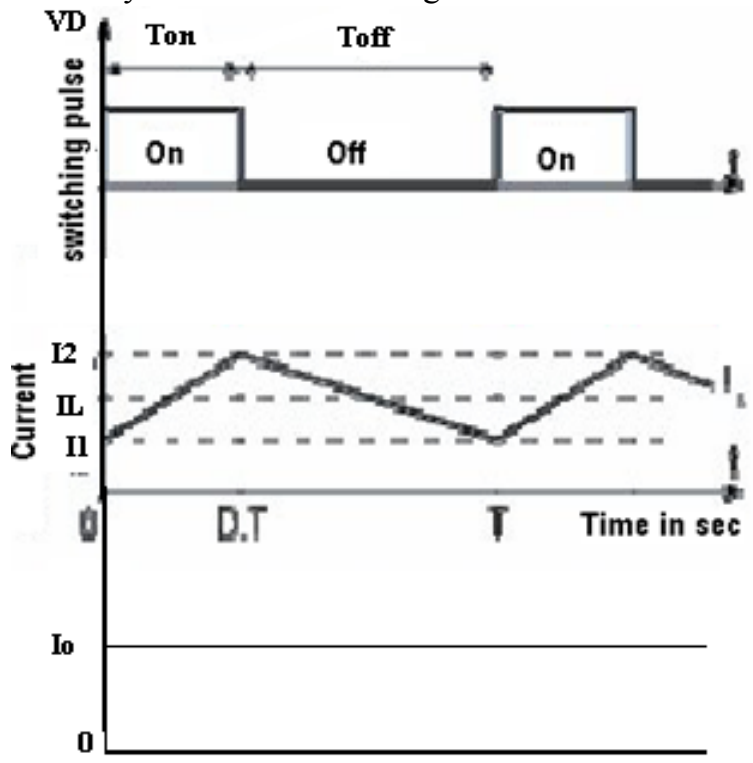

Fig4. An ideal Buck converter operating in continuous mode

By varying the duty-cycle Ton / $\mathrm{T}$ of the switch, V0 the output voltage can be controlled. The voltage on the diode is fluctuating between 0 and Vin, but this is not acceptable in most of the applications. For this reason an inductor is necessary. In continuous-conduction mode, since in steady state the time integral of the inductor voltage over one time period must be zero. Consequently, in average value over the switching period $(\mathrm{T})$ given by the following equation

$$
\begin{aligned}
& (\text { Vin }- \text { Vo }) \text { Ton }=\text { Vo }(T-T o n) \\
& \text { where } \operatorname{Vo} / \text { Vin }=\text { Ton } / T=D
\end{aligned}
$$

This means that the output voltage varies linearly with the duty-cycle. Assuming a lossless circuit, the input power Pin must be equal to the output power Po. It yields,

And

$$
\text { Vin Iin }=\text { VoIo }
$$

$$
\text { Io } / \text { Iin }=\mathrm{Vin} / \mathrm{Vo}=1 / \mathrm{D}
$$

The equations of buck converter are as follows:

The average output voltage is given as,

$$
\mathrm{Vo}(\mathrm{avg})=\mathrm{DVin}
$$

The ripple in output voltage is given as,

$$
\text { Vo(ripple })=\operatorname{Vin}(1-\mathrm{D}) \mathrm{D} / 8 \mathrm{LCf} 2
$$

And the ripple in output current is given as,

$$
\text { Io(ripple })=\operatorname{Vin}(1-\mathrm{D}) \mathrm{D} / \mathrm{fL}
$$


where Vin is the input voltage, $\mathrm{D}$ is the duty cycle ratio, $\mathrm{L}$ is the inductance and $f$ is the frequency of the buck converter.

Therefore, in the continuous-conduction mode, the Buck converter is equivalent to a DC transformer whose the turn ratio can be continuously controlled in a range from 0 to 1 .

The Buck converter model presented as a modulated transformer is an ideal element that does not refract actually the energy conversion. For this, we have investigated to the refinement of the buck model by predicting and integrating the device conduction and switching losses in the Buck model.

The conduction losses are due to the device conduction characteristics. The conduction losses are function currents and depend on device characteristics. To find out the device conduction losses, we need to model the device static I-V characteristics. Their information is usually available from manufacturer's data sheets. Conduction losses in the semiconductor devices are then approximated using a piece-wise linear approximation of the device's on-voltage characteristics. The switching losses are a function of the switching frequency, the current in each device, and the device's dynamic characteristics. Switching losses include devices turn-on loss, turn-off loss and reverse recovery loss. The turn-on loss is calculated according to the voltage and current waveform during the turn-on / turn-off transition.

\section{Simulation Results}

Simulation is done using Matlab and the results are presented. The simulation model of Buck converter for solar installation system is shown in Fig 5a. The DC input voltage is shown in Fig $5 \mathrm{~b}$. The driving pulses of the MOSFET are shown in Fig 5c.The DC output voltage is shown in Fig 5d. The output voltage reaches $5 \mathrm{~V}$. Output voltage is free from ripple. The DC output current is shown in Fig $5 \mathrm{e}$, it is 4.171A.

The open loop system with disturbance at the input is shown in Fig 6a. An external disturbance of step rise in input voltage of $5 \mathrm{~V}$ is applied at $\mathrm{t}=7 \mathrm{sec}$ as shown in Fig $6 \mathrm{~b}$. At 7 sec, the output voltage increases from 5 to $6.7 \mathrm{~V}$ as shown in the Fig $6 \mathrm{c}$.

The closed loop system with disturbance is shown in Fig 7a. The input and output voltages with disturbance of the closed loop DC to DC buck converter are shown in Figs $7 b \& 7 c$ respectively. Output voltage is sensed and it is compared with a reference voltage. At $7 \mathrm{sec}$, the output voltage is increased to $6.7 \mathrm{~V}$. Then the error is processed by a PI controller. The output of PI controller adjusts the pulse width to maintain the output voltage constant. The output voltage reduces and reaches the set value. PI controller uses the following equation.

$$
\mathrm{V} 0=\mathrm{kpe}+\mathrm{kI} \int \mathrm{edt}
$$

The proportional and integral gain values are 0.1 and 10 respectively.

The data used for simulation studies is as follows:

\begin{tabular}{|c|c|c|c|}
\hline \multirow{2}{*}{ Parameter } & \multicolumn{3}{|c|}{ Value } \\
\cline { 2 - 4 } & $\begin{array}{c}\text { Open loop } \\
\text { system } \\
\text { without } \\
\text { disturbance }\end{array}$ & $\begin{array}{c}\text { Open loop } \\
\text { system with } \\
\text { disturbance }\end{array}$ & $\begin{array}{c}\text { Closed } \\
\text { loop } \\
\text { system } \\
\text { with } \\
\text { disturba } \\
\text { nce }\end{array}$ \\
\hline Input voltage & $15 \mathrm{~V}$ & $20 \mathrm{~V}$ & $20 \mathrm{~V}$ \\
\hline Output voltage & $5 \mathrm{~V}$ & $6.7 \mathrm{~V}$ & $5 \mathrm{~V}$ \\
\hline Duty cycle ratio & $30 \%$ & $30 \%$ & $30 \%$ \\
\hline $\begin{array}{c}\text { Series } \\
\text { Resistance(Rs) }\end{array}$ & $1 \Omega$ & $1 \Omega$ & $1 \Omega$ \\
\hline $\begin{array}{c}\text { Parallel } \\
\text { Resistance(Rp) }\end{array}$ & $100 \mathrm{~K} \Omega$ & $100 \mathrm{~K} \Omega$ & $100 \mathrm{~K} \Omega$ \\
\hline $\begin{array}{c}\text { Inductance } \\
(\mathrm{L} 1 \& \mathrm{~L} 2)\end{array}$ & $3 \mathrm{mH}$ & $3 \mathrm{mH}$ & $3 \mathrm{mH}$ \\
\hline $\begin{array}{c}\text { Capacitance } \\
(\mathrm{C} 1 \& \mathrm{C} 2)\end{array}$ & $1000 \mu \mathrm{F}$ & $1000 \mu \mathrm{F}$ & $1000 \mu \mathrm{F}$ \\
\hline $\begin{array}{c}\text { Load } \\
\text { Resistance(R) }\end{array}$ & $1.2 \Omega$ & $1.2 \Omega$ & $1.2 \Omega$ \\
\hline
\end{tabular}

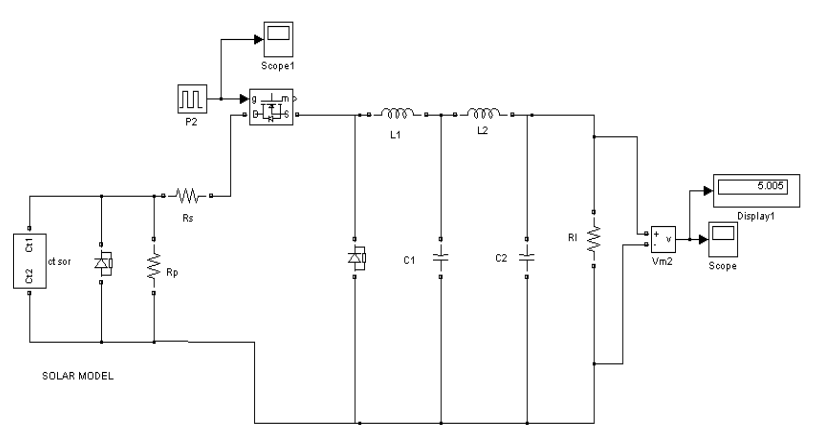

Fig5a. Simulink circuit of solar installation system

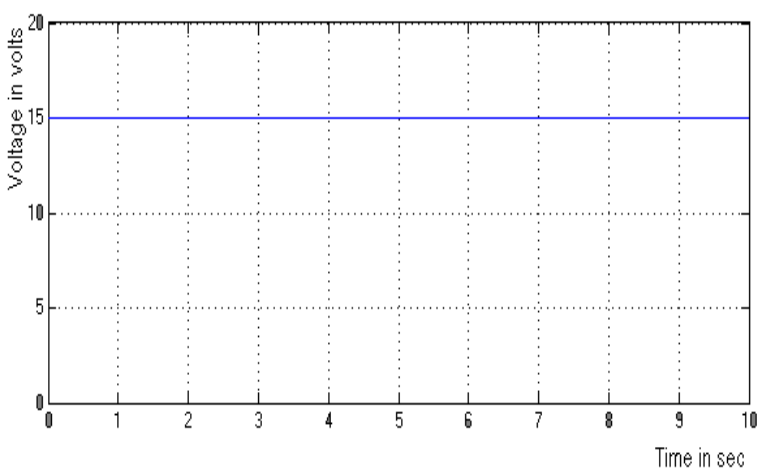

Fig5b. Inputvoltage

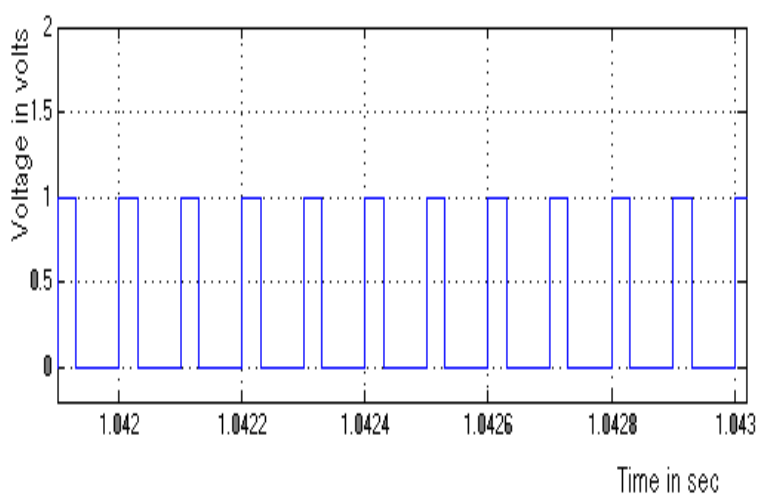

Fig5c. Driving pulses 


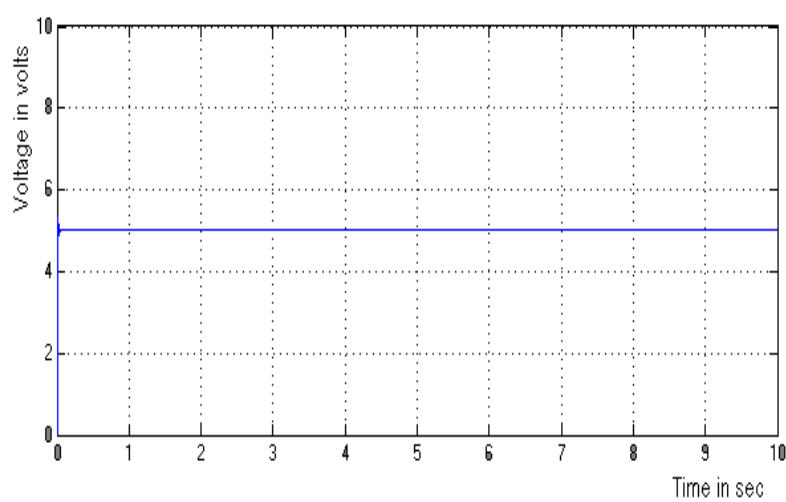

Fig5d. DC Output voltage

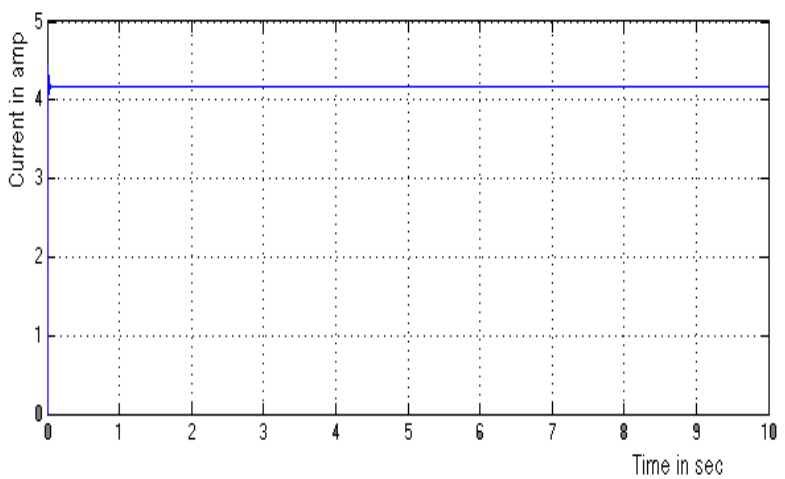

Fig5e. DC Output current

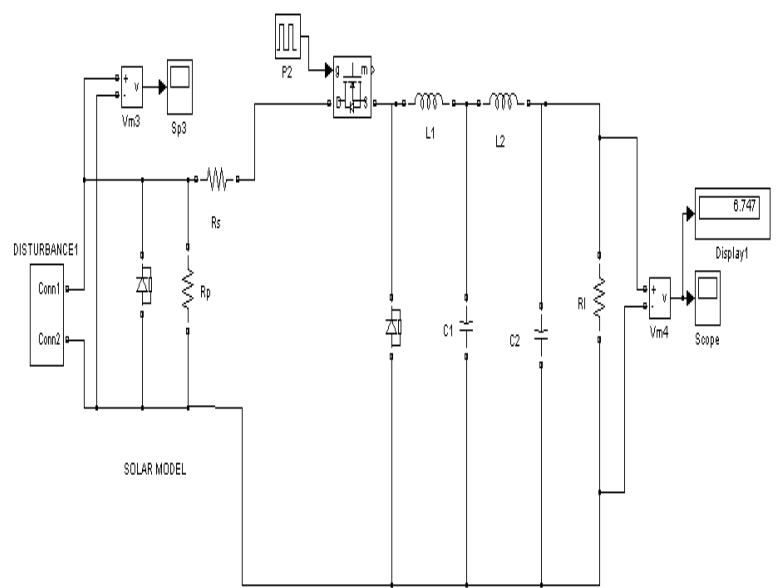

Fig6a. Open loop system with external disturbance at the input

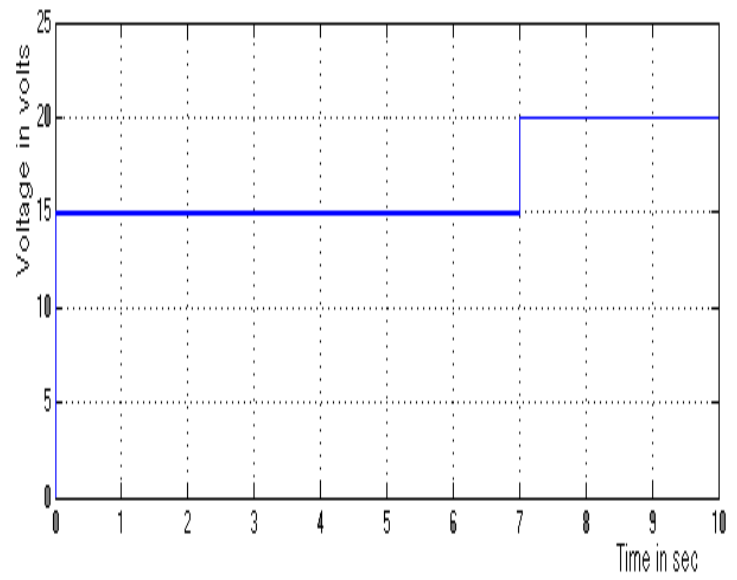

Fig6b. Input voltage with disturbance

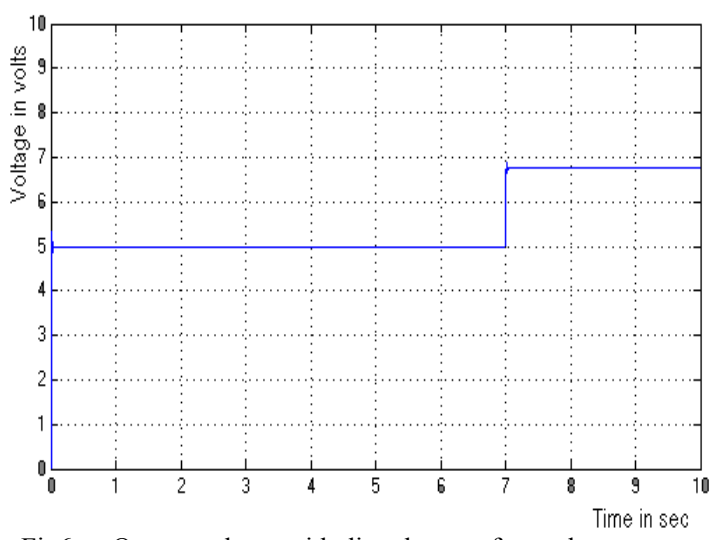

Fig6c. Output voltage with disturbance of open loop system

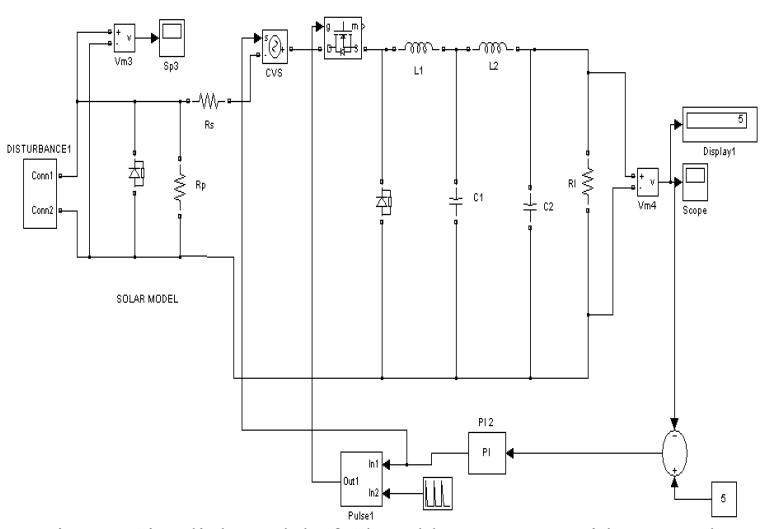

Fig7a. Simulink model of Closed loop system with external disturbance at the input

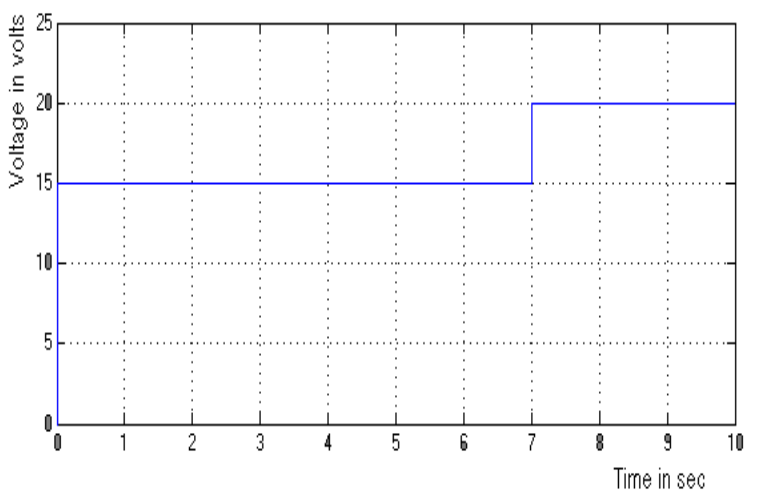

Fig7b. Input voltage with disturbance

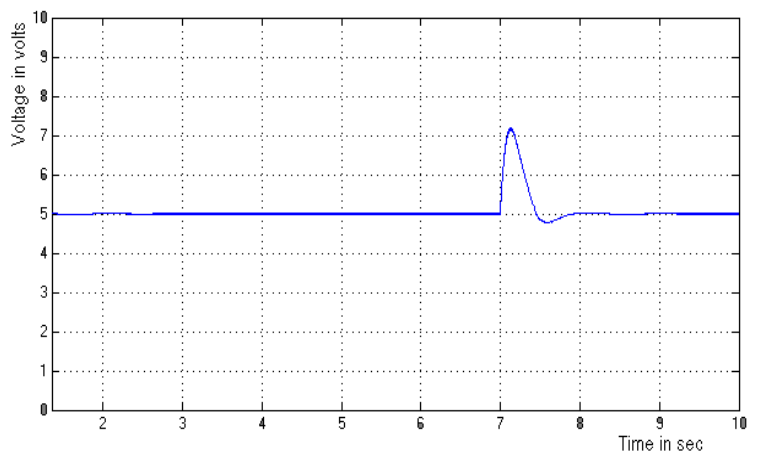

Fig7c. Output voltage with disturbance of closed loop system

\section{CONCLUSION}

This paper presents simulation of open loop and closed loop controlled buck converter system for solar installation system. Matlab models for open loop and closed loop systems are developed using the blocks of simulink and the 
same are used for simulation studies. The closed loop system is able to maintain constant voltage. This converter has advantages like reduced hardware and good output voltage regulation. The simulation results are in line with the theoretical predictions.

\section{REFERENCES}

[1] J.M. Enrique, E. Duran, M. Sidrach de Cardona, J.M. Andujar, M.A Bohorquez, J. Carratero, "A new approach to obtain I-V and P-V curves of photovoltaic modules by using DC/DC converters", - Rec. IEEE Photovoltaic Specialist Conference, 2005, pp. 1769-1722.

[2] Duran, E.; Enrique, J.M.; Bohorquez, M.A.; Sidrach-de-Cardona, M.; Carretero, J.E.; Andujar, J.M., "A new application of the coupledinductors SEPIC converter to obtain I-V and P-V curves of photovoltaic modules", 2005 EPE Conference,11-14 Sept. 2005, pp P.1-P.10.

[3] Di Piazza M.C., Serporta C., Vitale G., “A DC/DC Converter Based Circuit Model for a Solar Photovoltaic Array", 21th European Photovoltaic Solar Energy Conference and Exibition, 4-8 Sept. 2006, Dresden, Germany, pp. 2726-2731.

[4] Sanchis, P.; Echeverria, I.; Ursua, A.; Alonso, O.; Gubia, E.; Marroyo, L., "Electronic converter for the analysis of photovoltaic arrays and inverters", IEEE Power Electronics Specialists Conference, PESC 03, Volume 4, 15-19 June 2003, pp.1748-1753.

[5] K. Khouzam, K. Hoffman, "Real-Time Simulation of Photovoltaic Modules", Solar Energy, Vol.56, no.6, 1996, pp. 521-526.

[6] J.Cabestany, L. Castaner, "Evaluation of solar cell parameters by non linear algorithms", Journal of Physics D: Appl. Phys., No.16, 1983, pp. 2547-2558.

[7] D. Sera, R. Teodorescu, P. Rodriguez, "PV panel model based on datasheet values", IEEE International Symposium on Industrial Electronics ISIE 07, June 4-7, 2007, pp.2392-2396.

[8] Mohan, Undeland, Robbins, Power Electronics. Converters, Applications and Design, Wiley, 1995.

[9] R. D. Middlebrook, S.Cuk, "A General Unified Approach to Modelling Switching Converter Power Stages", 1976 Power Electronics Specialists Conference Records, pp.18-34.

[10] J.M. Enrique, E. Duran, M. Sidrach de Cardona, J.M. Andujar, M.A.Bohorquez, J. Carratero, "A new approach to obtain I-V and P-V curves of photovoltaic modules by using DC/DC converters", - Rec. IEEEPhotovoltaic Specialist Conference, 2005, pp. 1769-1722.

[11] Di Piazza M.C., Serporta C., Vitale G., "A DC/DC Converter Based Circuit Model for a Solar Photovoltaic Array", 21th European Photovoltaic Solar Energy Conference and Exibition, 4-8 Sept. 2006, Dresden, Germany, pp. 2726-2731.
[12] Maurizio Cirrincione, Maria Carmela Di Piazza,Giuseppe Marsala, Marcello Pucci , Gianpaolo Vitale," Real Time Simulation of Renewable Sources by Model-Based Control of DC/DC Converters", IEEE Tran Power Electron. pp. 1548 - 1555, sep. 2008.

[13] Emil A. Jimenez Brea, Eduardo I. Ortiz-Rivera, IEEE Member, Andres Salazar-Llinas, Jesus Gonzalez-Llorente," Simple Photovoltaic Solar Cell Dynamic Sliding Mode Controlled Maximum Power Point Tracker for Battery Charging Applications", 25th annual IEEE Applied Electronics conference, pp.666-671, Feb 21-25,2010.

[14] Del Vecchio, P.; Timidei, A," Portable Photo-voltaic Stand-alone System, Operating at Very Low Power Conditions ", Clean Electrical Power, 2007. ICCEP '07. International Conference on ,pp387-398,2007.

[15] Soto, A.; de Castro, A.; Alou, P.; Cobos, J.A.; Uceda, J.; Lotfi, A," Analysis of the Buck Converter for Scaling the Supply Voltage of Digital Circuits ", Power Electronics, IEEE Transactions on Volume: 22 , Issue: 6 , pp: $2432-2443,2007$

[16] Mrabti, T.; El Ouariachi, M.; Tidhaf, B.; Kassmi, K.; Chadli, E," Regulation of electric power of photovoltaic generators with DC-DC converter (buck type) and MPPT command ", Multimedia Computing and Systems, 2009,International Conference on ICMCS '09.: pp: 322 326.

[17] Chiang, C.-Y.; Chen, C.-L, "Automatic gating control of lowest voltage switching for boundary mode buck converters", Power Electronics,IET Volume: 3 , Issue: 5 ,pp.649 - $656,2010$.

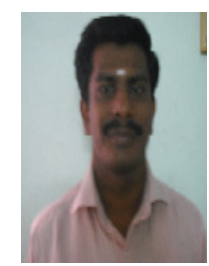

A.Kalirasu is a research scholar in sathyabama university, Chennai, India. He has 10 years of teaching experience. He has received B.E. degree in Electrical and Electronics Engineering from Madurai Kamaraj University, Madurai, India in the year of 2000. He has received M.E. degree in Power Electronics and industrial Drives Engineering from Sathyabama University, Chennai, India in the year of 2005. His current research interest is on solar converters. He is a member of IACSIT.

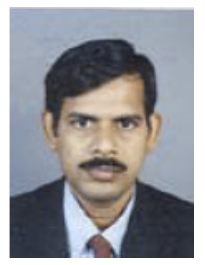

Dr.S.S Dash is a professor in SRM University, Chennai, India. He is having 14 years of teaching and research experience. He has received M.E. degree in Power System Engineering from University college of Engineering, Burla, India in the year of 1996. He obtained $\mathrm{PhD}$ in Electrical Engineering from Anna University, Chennai, India in the year 2006. His current research interest includes FACTS, drives, AI techniques 